\section{A unique opportunity to use football to improve birth registration awareness and completeness in Nigeria}

\author{
Olusesan Ayodeji Makinde, ${ }^{1,2,3}$ Clifford Obby Odimegwu, \\ Funmilola M OlaOlorun ${ }^{4}$
}

\begin{abstract}
Nigeria is a football-loving nation and has won silverware at international footballing events. By 2016, the country had won five of the under- 17 world championships that had ever been held since the tournament's inception in 1985 (16 tournaments). Brazil ranked next with number of three trophies. Nigeria also has the highest number of football players on the African continent, many of whom are youth. ${ }^{1}$ As at 2006 , there were over 6.5 million football players in the country, the eighth largest concentration of players in the world.
\end{abstract}

\section{THE BIGGEST PROBLEM FACING AFRICAN FOOTBALL}

Age-related footballing events have been bedevilled by age fraud. Age fraud is a term for age fabrication or the use of false documentation to gain an advantage over opponents and has been described as the 'biggest problem' facing African football. ${ }^{2}$ Nigeria has been repeatedly accused of being involved in age fraud and several of its players have been disqualified from different events. The country was suspended by FIFA in 1989 and stripped of its hosting rights for the FIFA world youth championship in 1991 after three of the players who it presented in a previous contest had disparities in age documents across different events. ${ }^{3}$

To address age fraud, FIFA in 2009 introduced MRI screening as a means of determining a participant's age. ${ }^{5}$ This introduction was expected to guaranty equal chances for countries participating in the age-related events. Since the introduction of MRI screening, this technique is believed to have reduced the incidence of age-related fraud significantly. ${ }^{6}$

'Demography and Population Studies Program, Schools of Public Health and Social Sciences, University of the Witwatersrand, Johannesburg, South Africa ${ }^{2}$ MEASURE Evaluation/John Snow Inc., Abuja, Nigeria ${ }^{3}$ Viable Knowledge Masters, Abuja, Nigeria

${ }^{4}$ Department of Community Medicine, College of Medicine, University of Ibadan, Ibadan, Nigeria

Correspondence to Dr Olusesan Ayodeji Makinde, Viable Knowledge Masters, 22 Olusegun Obasanjo Street, Peace Court Estate, Lokogoma, Abuja, Nigeria; sesmak@gmail.com

\section{FOOTBALL AS A TOOL AGAINST AGE FRAUD}

In August 2016, ahead of an African qualifier between Nigeria and the Niger Republic, MRI screening was carried out on the Nigerian contingent and revealed that 26 members of the Nigerian team were above the age limit and subsequently disqualified from the tournament. ${ }^{4}$ This discovery came barely 1 year after Nigeria had won its latest under- 17 world championship tournament.

Age fraud is prevalent in Nigeria because of the poor compliance with the civil registration and vital statistics (CRVS) system in the country. Despite Nigeria being a signatory to the Convention on the Rights of the Child, and prior legislation establishing compulsory birth registration since 1917 , many children are still not registered with the authorities at birth. ${ }^{78}$ As such, many parents do not obtain birth certificates for their children. While some footballers genuinely do not possess birth certificates for this reason, there is speculation that some individuals may use the poor compliance with the CRVS as an opening to modify their date of birth.

A national survey in 2013 estimated birth registration completeness among under-five children in the country to be about $31 \%$ with variations across states. ${ }^{9}$ Footballers, like every other Nigerian, are able to claim that their births were not formally registered. Thus, they do not have birth certificates to verify their age.

In its place, footballers can present a declaration of age document, which is a sworn affidavit by a relative stating that he/she is aware of the day that the child was born.

It is while obtaining this declaration of age/date of birth document that most of the manipulations in the dates of birth occur. Should birth registration be implemented as a compulsory requirement for school enrolment and formal sport participation, the incidence of age fraud would be significantly curtailed.

\section{CALL TO ACTION}

With the level of interest and followership of football in Nigeria, the National Population Commission needs to seize this unique opportunity to raise awareness of the Nigerian population on the importance of birth registration immediately after birth. The recent disqualification of 26 players from the under-17 national team is an immediate example of why a birth certificate is important and why presentation of this certificate should be the standard for age determination in age-related sporting events. At the same time, the National Population Commission needs to begin to formally discuss with the Ministry of Sports and other government agencies on the need to set a target date when participants without a birth certificate will not be permitted to feature in age-related sporting events. This target date can then be used in communication jingles to further raise awareness on the importance of birth registration. It should be stated expressly that the absence of a birth certificate will automatically disqualify a candidate from participating and representing the country in an age-bound sporting event. This effort will help to foster national pride, which has been repeatedly battered by the discovery of overaged players among representatives of the country at international age-related footballing events.

Special communication jingles over the radio, television and billboards could also be employed to improve awareness. Figure 1 shows how simple infographics may be used to relay this information. This opportunity to use the passion of the nation in football to foster a national development cause will not always present itself. It needs to be taken advantage of to raise awareness and move the country toward universal birth registration by 2030.

Funding $\mathrm{COO}, \mathrm{OAM}$ and FMO jointly conceived and drafted this discussion. All authors have read and agree to the final version of the discussion.

Funding This work is based on the research supported in part by the National Research Foundation of South Africa (Grant numbers: 105931) http://www.nrf.ac.za/.

Competing interests None declared.

Provenance and peer review Not commissioned; externally peer reviewed.

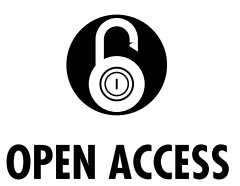

Open access This is an open access article distributed in accordance with the Creative Commons Attribution 


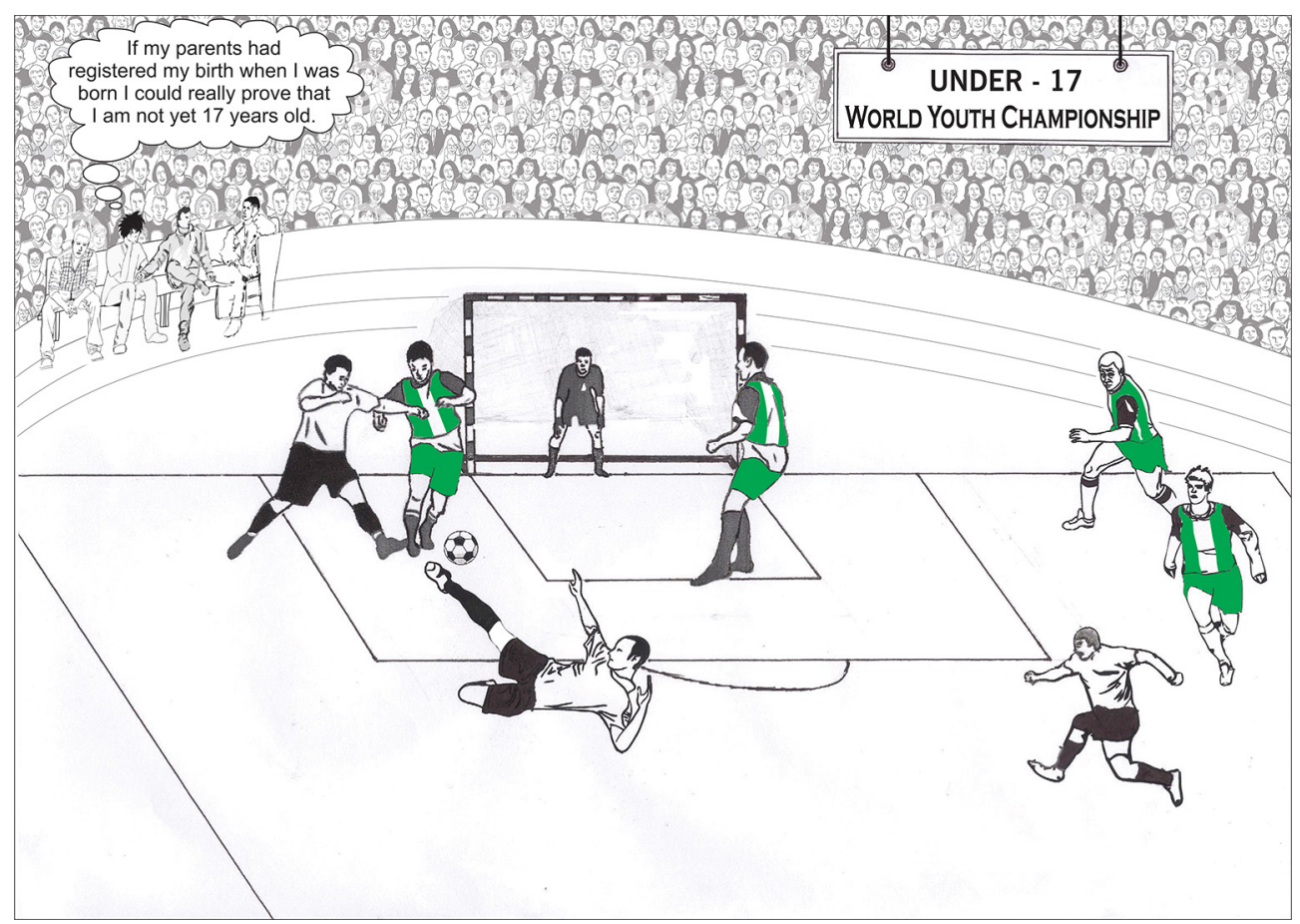

Non Commercial (CC BY-NC 4.0) license, which permits others to distribute, remix, adapt, build upon this work non-commercially, and license their derivative works on different terms, provided the original work is properly cited and the use is non-commercial. See: http:// creativecommons.org/licenses/by-nc/4.0/

(c) Article author(s) (or their employer(s) unless otherwise stated in the text of the article) 2018. All rights reserved. No commercial use is permitted unless otherwise expressly granted.

\section{Check for updates}

To cite Makinde OA, Odimegwu CO, OlaOlorun FM. Br J Sports Med 2018;52:1529-1530.

Accepted 27 March 2017

Published Online First 28 April 2017

Br J Sports Med 2018;52:1529-1530. doi:10.1136/bjsports-2016-097404

\section{REFERENCES}

1 FIFA. FIFA big count 2006: 270 million people active in football.2007 http://www.fifa.com/mm/document/ fifafacts/bcoffsurv/bigcount.statspackage\% $5 f 7024$.pd (accessed 29 Jan 2017).

2 Kaytee R. Age fraud the 'biggest problem' facing African football | football. News Hub 2014 https://www. the-newshub.com/football/age-fraud-the-\%22biggestproblem\%22-facing-african-football (accessed 6 Sep 2016)

3 Konig R. 7 of the biggest football scandals in recent history. Yahoo News 2016 https://in.news.yahoo.com/ 7-biggest-football-scandals-recent-123505796.html (accessed 30 Jan 2017).

4 News BBC. Nigeria's under-17 squad wiped out as half are older than 17 2016. http://www.bbc.co.uk/newsbeat/ article/36990537/nigerias-under-17-squad-wiped-out-ashalf-are-older-than-17 (accessed 5 Sep 2016).
5 Dvorak J, George J, Junge A, et al. Age determination by magnetic resonance imaging of the wrist in adolescent male football players. Br I Sports Med 2007;41:45-52.

6 Dvorak J, George J, Junge A, et al. Application of MR of the wrist for age determination in international U-17 soccer competitions. Br J Sports Med 2007:41:497-500. http://bjsm.bmj.com/content/41/8/ 497.short

7 Makinde OA, Olapeju B, Ogbuoji O, et al. Trends in the completeness of birth registration in Nigeria: 20022010. Demogr Res 2016;35:315-38.

8 UNICEF. Convention on the rights of the child. 1989 http://digitalcommons.ilr.cornell.edu/cgi/viewcontent. cgi? article $=1007 \&$ context $=$ child (accessed $29 \mathrm{Apr}$ 2014)

9 National Population Commission, Federal Republic of Nigeria, ICF International, Maryland USA. Nigeria demographic and health survey 2013. Abuja, Nigeria \& Rockville, Maryland, USA: National Population Commission, 2014 